\title{
TRADITIONAL BIRTH ATTENDANTS IN MALAWI
}

\author{
JJM Smit
}

\section{OPSOMMING}

Tradisionele vroedvroue en tradisionele helers is $n$ baie belangrike skakel in die ketting van gesondheidspersoneel wat primere gesondheidsorg in Malawi verskaf

Ten spyte van die oprigting van hospitale en gesondheidsentrums is dit tot hierdie tradisionele vroedvroue en tradisionele helers waartoe die mense hulself ten tye van siekte en geboorte wend. Ongeveer 60 persent van alle bevallings in Malawi vind in die dorpies plaas. Dit is dus belangrik dat die nodige aandag aan die verskillende aktiwiteite van hierdie tradisionele praktisyns gegee word on die doel van - "gesondheid vir almal in die jaar 2000", soos in Malawi toegepas, bereik word. Die opleiding van tradisionele vroedvroue vorm deel van die Moeder en Kindersorgdienste in die land.

Die Departement van Gesondheid is verantwoordelik vir die opleiding en beheer van tradisionele vroedvroue. In 1976 het die Departement van Gesondheid 'n register begin om die tradisionele vroedvroue wat alreeds opgelei is, aan te teken. Vroeg in 1978 is 'n opleidingskursus vir geselekteerde tradisionele vroedtroue in die Kamuzu Hospitaal in Lilongwe, aangebied. Vanaf 1982 het die

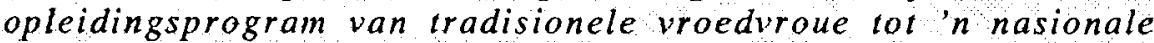
opleidingsprogram ontwikkel. 'n Totaal van 841 tradisionele vroedvroue is tot 1987 opgelei en die progran word steeds voortgesit.

\section{ABSTRACT}

Traditional Birth Attendants (TBAs) and traditional healers form an important link in the chain of health personnel providing primary health care in Malawi. In spite of the establishment of hospitals and health centres, it is to these traditional healers and TBAs that the majority of people turn in times of sickness and child-birth. Approximately 60 per cent of all deliveries in Malawi occur in the villages. It is therefore important that due regard be paid to the activities of these traditional practitioners in order to ensure the achievement of the goal. "Health for all by the year 2000". The training of TBAs is seen as part of the Maternal and Child Health Services in the country.

The Ministry of Health is responsible for the training and control of Traditional Birth Attendants and in 1976 opened a register in order to list all those trained In early 1978 a training course for selected TBAs was conducted at the Kamuzu Central Hospital, Lilongwe and from 1982 the training programme evolved into a national training programme for TBAs. By February 1987, a total of 841 Traditional birth Attendants hadbeen trained and the programme is still continuing.

\section{INTRODUCTION}

Approximately 60 per cent of all deliveries in Malawi occur in the villages, where the patient receives primary care either from a close relative or another village woman acts as village midwife. These women are called Traditional Birth Attendants (TBAs). Before 1978, when training courses were conducted for such workers, the care that they provided, although undoubtedly loving, was on the whole unskilled, misdirected and harmful. In
1973 the Secretary for Health in Malawi authorized an investigation into home deliveries in the Zomba and Machinga districts, and in 1976 in the Lilongwe district (Bullough 1978).

\section{TIE TYPICAL MALAWIAN TRADITIONAL BIRTH ATTENDANT}

Based on the above investigations, characteristics of the Malawian TBA emerged.
The Malawian TBA is almost invariably a female, aged between 35 and 60 years. She begins her midwifery work only after she has had children of her own, and usually learns from some close relative who is an established TBA. She performs from 1 to 25 deliveries monthly, charging between 20 cents and R3.00 per delivery. A few do not charge. Two-thirds of TBAs carry out deliveries in the patient's own home, sometimes being called at the onset of labour, but sometimes only later when difficulties arise. The remaining one-third have their own maternity units and tend to do more deliveries, to charge more, and to deal with normal cases rather than problem cases.

The TBA usually sees her patients antenatally and prescribes potions made from powdered bark, roots or twigs. She often administers similar medicine during labour. Nearly all TBAs want closer association with the recognised health services and welcome the idea of receiving training. Those with maternity units in their own homes are more uniformly positive about this than the others. The maternity units of these TBAs are typically a mud and thatch house partitioned to divide the labour ward from the post-natal or waiting area. Some, however, have several buildings, for waiting patients, antenatal clinics, premature baby nurseries, and some have corrugated iron roofs. The TBAs seem to select themselves for their work, and without an aptitude for and an interest in their work are unlikely to embark on it. The few apprentice TBAs in the survey conducted by the Ministry of Health, often "looked the brightest and most intelligent of the younger women available in the village" (Bullough, 1978:83).

The investigation into TBAs by the Ministry of Health (MOH) revealed that their management of labour is based on different principles from those of Western medicine. They have, however, adopted some Western practices on their own initiative. For example, TBAs deliver their patients in the supine position whereas most home deliveries conducted by relatives are believed to be managed with the mother in a semi-upright, sitting or squatting position.

The TBA is prepared to care for premature babies, deal with abortions and treat women for infertility and other gynaecological diseases. They do not concern themselves with children's diseases. A small number, are also 
traditional healers and then they treat all forms of disease and include children amongst their patients (Bullough, 1978: 83)

\section{TRAINING OF TRADITIONAL BIRTII ATTENDANTS}

After the investigation by the MOI this body approached the Nurses and Midwives Council of Malawi (NMCM) to ask the Council to establish a training course for a grade of midwives who were willing to work in the rural areas. The Council suggested that the training should last between six weeks and three months (MNCM, 1976).

It was then decided that the MOH should be responsible for the training and control of TBAs and in 1976 the Ministry opened a register in order to list all trained TBs. It was suggested that these women be left independent of the normal medical services, and kept free from oppressive paperwork and reports. This would preserve their dignity and at the same time ensure that costs did not escalate (Bullough, 1978: 83).

In early 1978 a training course for 15 TBAs was conducted at Kamuzu Central Hospital, Lilongwe; they were selected from amongst those who carried out deliveries in their own maternity unit, and who performed five or more deliveries per month. They came for two weeks training in groups of three and four, and afterwards had three follow-up visits.

The syllabus included instruction in hygiene, the normal events of pregnancy and labour, the recognition of women at risk of obstetric abnormalities, the management of labour, the puerperium and the new-born child. Some child care and development was taught. Great emphasis was placed on the fact that normal labour is short and that referral to hospital is essential when delay occurs.

The basic concept stressed was that their job was to manage normal labour in a safe way, but that abnormalities of labour were the concern of hospital staff. It was emphasised that they could improve their results and reputation by learning to select and recognise patients who might experience problem labours, and then refer them to hospital.

On completion of the residential course they were issued with United Nations International Children's Emergency Fund (UNICEF) midwifery bags. This bag is made of stainless steel and contains the following items needed during a delivery: a plastic apron, a plastic sheet, a pair of scissors, a kidney dish, two round stainless steel bowls, a pair of cheatles, a scrubbing brush, a pair of scissors, soap in a dish, cottonwool, gauze, swabs for wiping the eyes of the baby and protargol eye drops to instill into the eyes of the baby afterbirth. Other useful items of equipment such as hurricane lamps, blankets and soap were also given (Bullough, 1978, 84). An interview with TBA Mrs Marika Naphira, showed the author the contents of her midwifery bag, in October 1987.

\section{EVALUATION OF THE INITIAL TRAINING PROGRAMME}

The efficacy of this first training programme was assessed during a fourth and final home visit when a questionnaire, used before training had begun, was repeated. Records of deliveries performed were examined and the equipment issued to them inspected. The training team of the MOH was pleased with the results and related that the personal relationships with the TBAs had been excellent, and that a considerable degree of mutual trust had developed. Referred patients arrived in considerable numbers, including antenatal patients with labour complications, and puerperal infections (Bullough, 1978, 84).

Much building activity was stimulated by the first course arranged by the MOH during 1978 , many of the participants having since extended or improved their premises. Before the course, all but one were delivering their patients on the ground, but since then, many have had labour beds constructed al though no mention was made of this being necessary or desirable. The benefits of this first training course were compared with the costs. There were many hidden costs such as use of staff time, but approximated costs were:-

Transport (for six visits to each Traditional Birth Attendant)

K1 275.00

Equipment

K 700.00

Food

K 105.00

TOTAL

K2 080.00

However, these 15 TBAs are responsible for about 2000 deliveries per year, and no further cost, except for occasional follow-up visits, need be expected. Their combined work-load is equivalent to that of four or five small two-midwife maternity units.

\section{NATIONAL TRAINING PROGRAMME}

Bullough (1978) hoped that these results would be considered positively enough to warrant the introduction of a National Programme for training the TBA. He suggested that such a programme would be best arranged in the form of an initial saturation programme trying to cover the country and then later as a smaller programme maintaining supervision, which would be essential, and running smaller numbers of new courses. It was pointed out that TBAs only conducted a minority of village deliveries during 1978, but it was postulated that a national training programme would increase their influence, make them more successful and increase the amount of work they do. In this way the effects of their training could spread to affect all home deliveries (Bullough, $1978,84-85$ ).

The vision regarding a National Training Programme for Traditional Birth Attendants became a reality through the hard work and enthusiasm of Dr C. Bullough and the medical and nursing staff of the MOH with the co-operation of the Private Hospital Association of Malawi (PHAM) personnel. The training programme started in 1978 in the district of Lilongwe and three more districts were added in 1980, namely Mzimba, Dowa and Mwanza; training was extended to cover the whole country in 1982 . The training programme was implemented in support of the main objective of the Maternal and Child Health Programme enunciated in the Minimum Plan, Miniplan, which is:

"... to increase protection of the high risk group, that is children, under the age of five years and mothers in the child-bearing age, against causes of high morbidity and mortality" (Ministry of Health 1987; 2)

\section{INCREASING NUMBERS OF TRAINED TRADITIONAL BIRTH ATTENDANTS}

By February 1987, a total of 841 TBAs had been trained and the programme is still continuing. Table 1 shows that the number has been increasing constantly since 1982, with an average annual increase of 148 . This is a considerable achievement in view of staff shortages and difficulties with identification of untrained TBAs. Districts are encouraged to train ten women per year if adequate identification can be achieved. TBAs are not selected in proportion to population density and there is no national target as the number of untrained Attendants is unknown. (See Table 1)

\section{METHODS AND COURSE CONTENT}

The training courses are held in the Ministry of Health and PHAM hospitals. The course extends over four weeks using the following educational methods:

\section{- Lectures}

\section{- Observation}

\section{- Discussions}

- Role play

- Demonstrations

- Practice

- Evaluation exercises.

- Field trips to see pit latrines and protected well projects.

- Familiarization tours to health centre(s), children's wards, care of the new-born units, "under five"-clinics and nutrition clinics.

- Social and extra-curricula activities over the weekends covering the following:

- Health-care and prevention of infections; 


\begin{tabular}{|lrrrrrrrr|}
\hline \multicolumn{7}{|c}{ Table 1: Trained Traditional Birth Attendants, $1978-1986$} \\
DISTRICT & $\mathbf{1 9 7 8}$ & 1980 & 1982 & 1983 & 1984 & 1985 & 1986 & TOTALS \\
Chitipa & Nil & Nil & Nil & 40 & 8 & 6 & 10 & 34 \\
Karonga & Nil & Nil & 7 & 10 & Nil & 9 & 10 & 36 \\
Rumphi & Nil & Nil & 8 & 9 & 10 & 7 & Nil & 34 \\
Mzimba & - & 6 & Nil & 5 & Nil & Nil & 9 & 20 \\
Nkhata Bay & Nil & Nil & 7 & 6 & 9 & 12 & 8 & 42 \\
Kasungu & Nil & Nil & 10 & 8 & 11 & 9 & 18 & 56 \\
Ntchisi & Nil & Nil & 8 & 7 & 7 & 10 & 9 & 41 \\
Dowa & Nil & 8 & 10 & 6 & 7 & 9 & Nil & 40 \\
Mchinji & Nil & Nil & 10 & 7 & 6 & Nil & 8 & 31 \\
Salima & Nil & Nil & 10 & 10 & 10 & 10 & 10 & 50 \\
Nkhotakota & Nil & Nil & Nil & 10 & 10 & Nil & 8 & 28 \\
Lilongwe & 15 & Nil & 10 & Nil & Nil & 10 & Nil & 35 \\
Dedza & Nil & Nil & 9 & 10 & Nil & 10 & Nil & 29 \\
Ntcheu & Nil & Nil & 9 & 8 & Nil & 8 & 10 & 35 \\
Mangochi & Nil & Nil & 9 & 10 & 6 & 8 & 10 & 43 \\
Machinga & Nil & Nil & 9 & 10 & 9 & Nil & 9 & 37 \\
Zomba & Nil & Nil & 10 & 8 & Nil & 7 & Nil & 25 \\
Mwanza & Nil & 5 & Nil & Nil & Nil & 10 & 14 & 29 \\
Chiradzulu & Nil & Nil & 9 & 8 & Nil & Nil & Nil & 17 \\
Blantyre & Nil & Nil & 9 & 8 & 8 & Nil & 20 & 45 \\
Thyolo & Nil & Nil & 9 & 9 & 9 & Nil & 9 & 36 \\
Chikwawa & Nil & Nil & 10 & 6 & 6 & 7 & 7 & 36 \\
Mulanje & Nil & 0 & 8 & 7 & 7 & Nil & Nil & 22 \\
Nsanje & Nil & Nil & 10 & 10 & 10 & 10 & Nil & 40 \\
TOTAL & 15 & 19 & 181 & 185 & 130 & 142 & 169 & 841 \\
(Ministry of Health & 1987.4). & & & & & & & \\
\hline
\end{tabular}

- Child-care and nutrition;

- Personal hygiene, environmental hygiene and sanitation;

- Management of antenatal clinic patients, that is, identification and referral of at-risk mothers to the nearest health centre;

- Use, management and care of UNICEF Traditional Birth Attendant kit;

- Management of labour, delivery, post-partum or perinatal care of the new-born;

- Recognition of obstetric complications that may arise during labour and delivery;

- The role of the health team, the TBA and her relationship with other primary health care workers;

(Ministry of Health, 1987 2-3). the participants with knowledge, skills and attitudes for planning, organising, implementing and evaluating a TBA training programme. Special attention was paid tolocal customs and needs.

The content of the training was:

1. Concept of culture and relation to health in a community.

2. Profile of the TBA

3. Review of the TBA syllabus.

4. Teaching methodology for a TBA programme.

5. Selection criteria and administrative aspects of the programme.

6. Assessment and supervision of the TBA including assessment of knowledge and use of delivery records and quarterly returns (Ministry of Health 1987; 51).

In April 1985, a National TBAT workshop was held in Lilongwe. The objectives of the workshop were:

1. To review critically the TBA's training activities and identify areas needing improvement.

2. To examine the TBA's activities and find out how other activities as recommended by the 1984 , Maternal and Child Health Review Mission, could be incorporated into their training and services (Ministry of Heal th 1987, 5).

One of the main recommendations was to incorporate refresher courses in the programme to include new areas of child spacing, malaria and diarrhoea management including use of chloroquine and oral rehydration solutions. This activity started in July 1985. By February 1987, 123 trained TBAs had undergone a week's refresher course. This activity is still continuing (Ministry of Heal th 1987, 5-6).

In tandem with the TBAs training programme, supervision was equally important for the functioning of the programme. As it was not possible for the personnel of the Head Office of the MOH to supervise all the trained women in their area, the Ministry decided to train specific personnel to educate TBA; they are called Traditional Birth Attendant Trainers (TBATs)

The first trainees' workshop was conducted in May 1981, followed by two further workshops in June and July 1982. Two nurses were trained from each district, that is, a Registered Community Health Nurse or Registered Nurse/Midwife or an Enrolled Nurse/Midwife or Enrolled Community Health Nurse. One of the two was the Matemal and Child Health Co-ordinator. No specific selection criteria were applied (Ministry of Health 1987:51).

The objective of these workshops was to equip
As special attention is paid during the training course to local customs and needs of the area, the TBATs use all sorts of material to show how these TBAs can function in their own surroundings. Teaching hygiene, for example, is emphasised in many ways. One example is the way in which women are shown how to wash their hands. The trainer uses water, soap, a maize cob, and a tin with a small hole in it, which is used as a running tap. This could also be taught with the aid of pictures. The cutting of the baby's cord is demonstrated by using a rope or a soft cotton belt, which is tied in two places, making knots. A razor blade is then used for cutting in between the two knots. For equipment to cut the cord, the women are taught to prepare the bigger matchbox in which they pack self-prepared boiled cord ligatures, a new razor blade and a piece of soap; they feel comfortable with this type of 
kit, and it can be maintained and cleaned easily (Chirambo, 1985:29).

\section{PERSONAL VISIT TO A TRADITIONAL BIRTH ATTENDANT}

During a visit in 1984 to a local TBA, Mrs Najere Kumwembe, (also registered as a traditional healer at Nanjira) the researcher found that she was combining traditional medicine very successfully with her modern scientific knowledge of obstetrics. She has built up a wide reputation since she started to practise there in 1968 because she has the ability to 'see inside the uterus' and spot any abnormalities immediately. The patient is then referred to the hospital at Lilongwe. After the abdominal palpation on an antenatal patient, she rubs medicine on the abdomen of the patient as well as on a hand mirror. The mirror is then held in front of the abdomen and 'reflects' the contents inside. According to her, it works like an X-ray photo. The medicine is made of roots of a certain tree which her husband obtains from the Dedza-district, and these roots are then boiled in a tin. Qualified nurses number among Mrs Kumwembe's patients. Her practice is inspected regularly by the $\mathrm{MOH}$ and she attends updating courses in midwifery when it is expected of her.

Mrs Kumwembe also functions as a traditional healer and treats 'mentally confused patients that scream and shout'. She gives them medicine consisting of dried roots which are first ground into powder, then sieved and mixed with water. The patient receives two teaspoonfuls of this mixture twice a day. The medicine calms the patient down but if the patient does not improve she refers the patient to the psychiatric hospital in Zomba (Visit to Mrs N. Kumwembe, 14 July 1984). This corresponds with a statement by Dr Stevenson that the local treatment of neuroses and hysteria may be as effective in many cases as the treatment which conventional medicine can offer (Stevenson, 1964:10).

\section{NATIONAL EVALUATION OF TRADITIONAL BIRTH ATTENDANT PROGRAMME}

Since the TBA's training programme started in 1978, no comprehensive national evaluation has been undertaken. During August 1980, the United Nation's Family Planning Assistance (UNDPA) programme, visited Malawi and gave their support to the programme and the evaluation of Maternal and Child Health services. The evaluation of the Traditional Birth Attendants' programme was then undertaken jointly during 1985 and 1986 by the Government of Malawi with WHO and UNFPA.

It was recommended that the TBA's programme becomes an integral part of the family health programme at national, regional and district level. This was implemented and the training of Traditional Birth Attendants is seen as part of the Maternal and Child Health Services (Ministry of Health, 1986, 7-13).
One of the main findings of the working group was that there was a need to increase the level of awareness among the community of the activities and role of the TBAs, and their participation in primary health care of Village Health Committees in order to extend coverage of maternal and child health. It was recommended that this orientation should be done by the trainer on completion of the TBA's training sessions, at community leadership meetings in their home areas after consultation with the TBAT. Community support for the TBAs needed strengthening, particularly with regard to referral of high risk mothers (Ministry of Health 1987, iii).

\section{SELECTION OF TRADITIONAI BIRTII ATTENDANTS}

Another recommendation of the review team was that in view of the fact that about 50 per cent of TBAs performed less than the minimum requirement of 24 deliveries per annum which was required for selection up to 1987, and 25 per cent performed less than 10 deliveries on average per annum, a new approach to their selection of needed to be implemented, based on the following five points:

1. Population the TBA is likely to be serving.

2. Proximity to other health facilities.

3. Visit to villages, discussion with village leaders and review of the workload of the TBA by the trainer before selection is made.

4. Identification of untrained TBAs should be an on-going process throughout the year through discussion with village leaders and untrained Attendants when encountered during outreach clinics, or by Health Surveillance Assistants.

5. Health Centre staff should be involved in the selection of TBAs (Ministry of Heal th 1987, v).

These recommended criteria are taken into consideration wherever possible when selecting women for training.

\section{SUMMARY}

Traditional healing is an established part of a culture. It is practised in various degrees in all cultures including the African culture. It should also be noted that traditional medicine still remains the only source of care for many people in developing countries, and for them primary health care is synonymous with traditional medicine. In Malawi, as in other African countries, traditional healers and TBAs play an important role in their communities, especially with regard to common ailments and mental disorders. In spite of the establishment of hospitals and health centres, it is to these traditional healers that the majority of people turn in times of sickness and child-birth. It is therefore imperative that all due regard should be paid to the various activities of these traditional practitioners in order to ensure the achievement of the goal - "Health for All by the Year 2000", as is done in Malawi. The Traditional Birth Attendants and traditional healers form an important link in the chain of health personnel providing primary health care in Malawi.

\section{REFERENCES}

BULLOUGH CHW (1978). Tradional Birth Attendants in Malawi, in Health for All. Malawi Ministry of Health: Lilongwe.

CHIRAMBO, M.T. 1985 A study of why the Traditional Birth Attendants are incorporated into the Primary Health Care plan of a developing country like Malawi. Unpublished dissertation submitted for BSC degree in Nursing Studies: University of Ulster.

MINISTRY OF HEALTH, (1978). Health for all, Report of the National Seminar on PHC, Llongwe, 30 October - 3 November. Malawi Ministry of Health: Llongwe.

MINISTRY OF HEALTH, (1986). The National Health Plan of Malawi, 1986 - 1995. Malawi Ministry of Health: Llongwe.

MINISTRY OF HEALTH,(1987). Report on Evaluation of Traditional Birth Attendants Programme, February. Malawi Ministry of Heal th: Llongwe.

Nurses and Midwives Council of Malawi (1976). Minutes of the Council, 16 November 1976. Malawi: Llongwe.

STEVENSON, D.J.D. (1964). The Health Services of Malawi, Unpublished thesis for the Degree of Doctor in Medicine. University of Glasgow.

Visits and interviews with Traditional Birth Attendants: undertaken by author

Mrs. Marika Naphira, Kumitawa Village, 21 October 1987.

Mrs. N. Kumwembe, Nanjira Village, 14 July 1984.

\section{Joyce Smit \\ D.CUR (U.P.E.) \\ Senior Lecturer \\ Department of Nursing University of Stellenbosch}

